\title{
1966 ANNUAL MEETING AND SLATE OF OFFICERS FOR 1966-67
}

The 1966 Annual Meeting of the Association will be held September 6-10 at the StatlerHilton Hotel, New York City. Professor Ithiel de Sola Pool, Massachusetts Institute of Technology, is Chairman of the Program Committee.

At the Annual Business Meeting of the Association, to be held at 4:30 P.M. Wednesday, Sept. 7, in the Georgian Room, Statler-Hilton Hotel, New York City, the Nominating Committee (comprised of Bernard C. Cohen, University of Wisconsin, Chairman; Gwendolen M. Carter, Northwestern University; Alfred Diamant, Haverford College; Robert Horn, Stanford University; Samuel P. Huntington, Harvard University; and Donald R. Matthews, University of North Carolina) will propose the following officers for 1966-67:

President Elect: Merle Fainsod, Harvard University

Vice Presidents: Avery Leiserson, Vanderbilt University

Richard C. Snyder, University of California, Irvine

Harold Stein, Princeton University

Secretary: Kenneth Waltz, Swarthmore College

Treasurer: Max M. Kampelman, Washington, D.C.

Members of the Council for two years:

M. Margaret Ball, Duke University

H. Paul Castleberry, Washington State University

Edgar S. Furniss, Jr., Ohio State University

Herbert Kaufman, Yale University

Charles A. McClelland, University of Southern California

Alfred G. Meyer, Michigan State University

Clara Penniman, University of Wisconsin

Clinton Rossiter, Cornell University

\section{PROGRAM COMMITTEE: 1967 ANNUAL MEETING}

The 1967 Annual Meeting of the Association will be held in Chicago at the Pick-Congress Hotel, September 5-9. Early appointment of the Program Committee for the meeting makes it timely now to invite anyone having program suggestions for the occasion to convey them as soon as convenient, and prior to October, 1966, to the Chairman or an appropriate member of the Committee. Members of the Committee are:

Chairman, Harry Eckstein, Princeton University

American Politics: National and Local-Allan P. Sindler, Cornell University

History of Political Thought-Melvin Richter, Hunter College

International Politics and Organization-Stanley Hoff mann, Harvard University

Authoritarian Political Systems--Robert C. Tucker, Princeton University

Political Development-Samuel P. Huntington, Harvard University

Comparative Political Behavior--Sidney Verba, Stanford University

Parties and Pressure Groups-Henry W. Ehrmann, Dartmouth College

Political Stratification (Power, Influence, Elites, Leadership)-Nelson W. Polsby,

Wesleyan University

Political Violence-James C. Davies, University of Oregon

The Political Science Curriculum-Vernon Van Dyke, University of Iowa

The Political and Social Sciences-Seymour Martin Lipset, Harvard University

The Program Committee invites younger members of the Association to submit papers for consideration to the appropriate section chairman listed above. This procedure replaces separately organized selected-paper or volunteer-paper panels but is designed to offer the same opportunity. To be considered, papers should be submitted no later than November 1, 1966. 